\title{
The Drava River Sword
}

\section{Meč z řeky Drávy}

\section{Marina Šimek}

\begin{abstract}
This paper talks about a well-preserved bronze sword found by accident in 2006 in the Drava River near Varaždin in Northwest Croatia. The sword was spotted by a gravel extraction worker. Shortly afterwards, it was purchased by the Varaždin City Museum. Since the sword is an isolated find, its chronological attribution was determined using typological characteristics. The sword is an atypical, unique find that combines features of the Sauerbrunn-Boiu Group and the straight blade swords of the Late Bronze Age.
\end{abstract}

\section{Keywords}

Croatia, Drava River, water find, Sauerbrunn-Boiu, sword for stabbing and hacking, Middle Bronze Age, Late Bronze Age

\begin{abstract}
Abstrakt
Článek pojednává o náhodném nálezu zachovalého bronzového meče, který byl objeven $v$ roce 2006 při těžbě štěrku v korytu řeky Drávy pobliž Varaždína na severozápadě Chorvatska. Krátce poté jej odkoupilo do svých sbírek Městské muzeum ve Varaždínu. Jelikož se jedná o ojedinělý nález, datování probíhalo na základě typologie. Meč představuje atypický a ojedinělý exemplár̆, na kterém můžeme pozorovat kombinaci prvků skupiny Sauerbrunn-Boiu a mečů s rovnou čepelí z mladši doby bronzové.
\end{abstract}

\section{Klíčová slova}

Chorvatsko, řeka Dráva, říční nález, Sauerbrunn-Boiu, meč bodný i sečný, střední doba bronzová, mladší doba bronzová 


\section{Introduction}

In 2006, during gravel extraction along the present day Drava riverbed near the city of Varaždin (northwest Croatia), a bronze sword ${ }^{1}$ was found (Fig. 1).

Workers who were extracting the gravel had in the last few months gathered several other more recent iron objects that were, along with the sword, offered to the Varaždin City Museum. By purchasing the finds, the Archaeological collection was enriched with a well-preserved decorated sword from the Bronze Age, which is for now the only find recovered from the Drava river in Croatia.

\section{The Site}

Gravel separation plant Beli kipi was operational up until a few years ago and it was situated on the south bank of the old Drava riverbed, about $6.5 \mathrm{~km}$ north of Varaždin. The gravel was extracted right next to the river, but also from the river itself, which of course influenced the natural balance of the landscape along the old riverbed. Meanders, backwaters, sandbanks, islets and dry riverbeds are characteristics of the preserved parts of the Drava river north and northwest of Varaždin (Fig. 2).

About $4 \mathrm{~km}$ downstream from Beli kipi, the river lost its natural characteristics when an artificial lake was built (Obadic 2007, 305, 317). Along its course through Croatia, Drava has in its recent history had the characteristics of a lowland, but powerful and fast river that often changed its course. The surrounding areas were prone to flooding, and after the withdrawal of water, forested lowlands were filled with ponds and marshes. Today, the depth of the river in the old riverbed is between 4 and $7 \mathrm{~m}$ (Obadic 2007, 303). At the site where the bronze sword was found, the depth achieved by gravel excavation was greater than $10 \mathrm{~m}$, but this information cannot be connected with the position of the weapon. The sword was noticed only when it got on the conveyor belt along with the gravel which means that the reconstruction of the original position is not possible. However, it is certain that this find comes from the Drava river so it should be attributed to the group of finds found in water, which have lately received a lot more attention (e.g. Potočnik 1989; Hansen 1997; Glogović 1998; Turk - Gaspari 2009; Chvojka - Jiráñ 2013). In 2006, the position of the gravel separation plant was within the big Drava meander which is mostly dry but still recognizable in the landscape. Only one part of it, a smaller branch, is filled with water. Gravel extraction inflicted great damage to the "water" landscape of the old riverbed and its coastal areas. As the extraction stopped and the area was partially rehabilitated (Fig. 3), a balance was gradually established in the damaged ecosystem of the Drava river which is slowly regaining its original appearance ${ }^{2}$.

\section{Description of the sword}

Dimensions: length of sword $57 \mathrm{~cm}$; butt: height $3.5 \mathrm{~cm}$, width $4.5 \mathrm{~cm}$, thickness $1-0.3$ $\mathrm{cm}$; blade: width $3-3.4 \mathrm{~cm}$, thickness $0.8 \mathrm{~cm}$; weight $594 \mathrm{~g}$. Varaždin City Museum, Inv. no. GMV-60156 (Fig. 4; 5).

The well preserved bronze sword belongs to a group of ornamented swords and, based on the length, to swords with a length of $45-70 \mathrm{~cm}$, defined by T. Kemenczei (Kemenczei 1988, 1). The hilt butt is reminiscent of the elongated triangular butts, Boiu Ia type (Neuman 2009, 98, Abb. 1), but how the hilt was fixed remains unknown because the butt was damaged. The butt was broken off over the rivet holes because this part was the thinnest, and therefore the most sensitive and susceptible to 


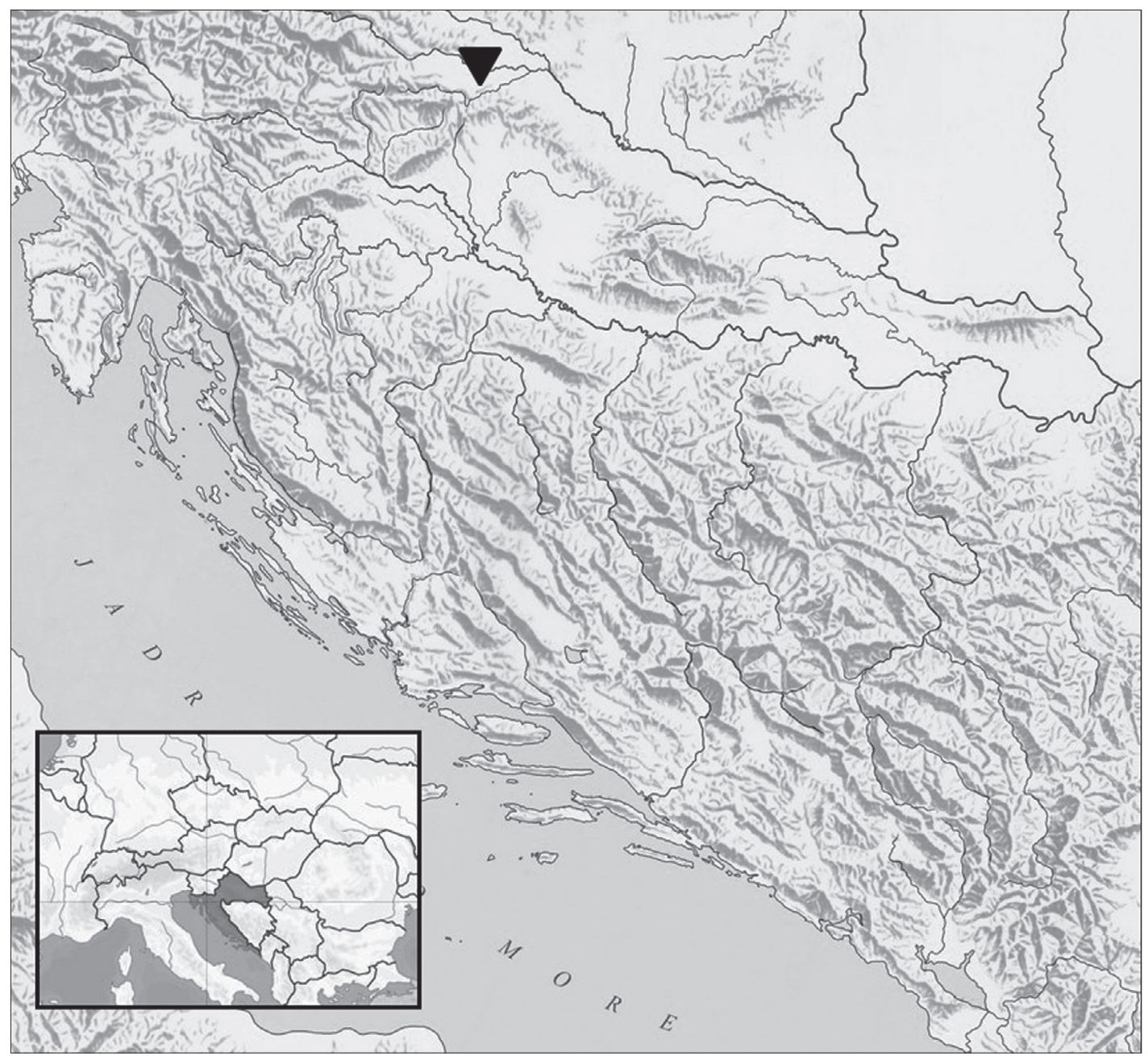

Obr. 1. Mapa Chorvatska s vyznačením nálezu meče.

Fig. 1. Map of Croatia with the location where the sword was found.

fracture. This is confirmed by the difference in thickness between the middle and the considerably thinner edge of the butt. On the damaged part, there are 6 discernible, most likely 8 , rivet holes. Both sides of the butt were decorated with an identical engraved spiral motif. While the ornament is clearly visible on one side, on the other one it is covered with a green patina and therefore more difficult to discern (Fig. 4: A, B). The upper part of the ornament consists of two circles side by side on both sides of an imaginary axis of the butt (Fig. 6). The circles are filled with densely engraved double spirals (ten lines in each one). Both motifs originate in the centre of the circle and both continue on the same side. The upper halfs of the circular ornaments are lined with a band filled with short vertical lines so the motif looks like eyes, and they may very be mystical eyes of the sword (Cowen 1966, 280, 294). 


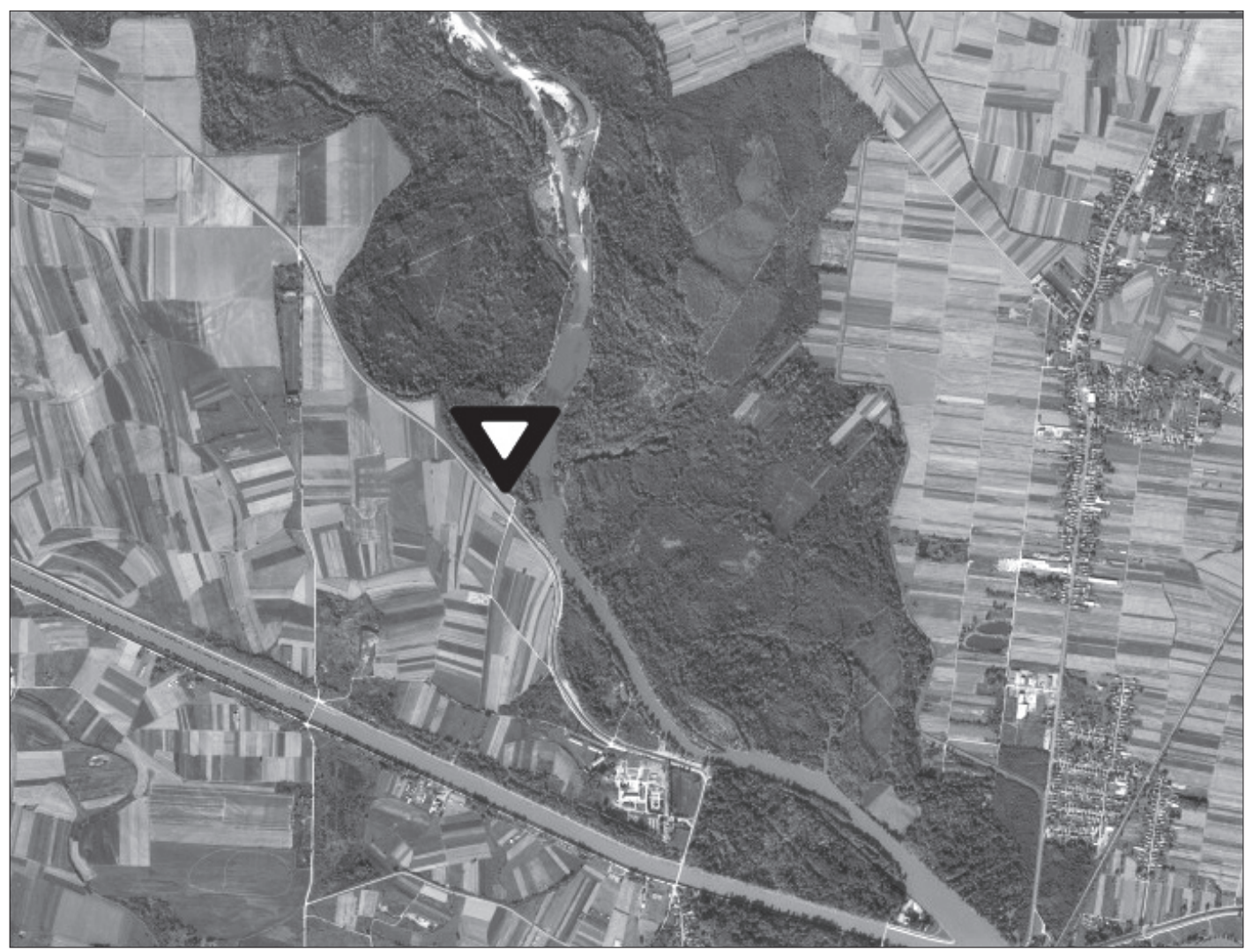

Obr. 2. Řeka Dráva u Varaždinu a lokalizace nálezu (http://preglednik.arkod.hr)

Fig. 2. Drava river near Varaždin and the location of the find (http://preglednik.arkod.hr)

Under the two bigger circles, in the same place based on the axis of the butt, there are two smaller ones that almost touch the bigger circles with their edges. Their interior decoration is the same as in the larger circles, only here there are eight engraved spiral lines, but the direction is the same. The entire ornament is engraved with lines of varying widths: all four circles and semi-circular bands are marked with thicker lines while the spirals in circles are made with finer, thin lines. The ornament transitions from the butt to the blade: from each of the lower circles one line goes along the length of the blade, and both lines form a point at the top (Fig. 5). The lines go along the middle of the blade and follow its width. In the upper part of the sword, on the transition between the butt and the blade, there are two additional engraved thin lines, set apart by $5 \mathrm{~mm}$, that follow the main lines but only for about $4 \mathrm{~cm}$. At the top, they follow the transition of the wider butt into the narrower blade. A similar situation is repeated on the pointed tip of the blade; two additional external lines (one on each side), go parallel with the primary lines for about $13 \mathrm{~cm}$, and also form a point. The same line pattern is present on the other side of the sword. The blade is slightly indented below the butt, and its edges are almost straight. Approximately in the middle, the blade is slightly wider, and the minimal change in width is followed by 


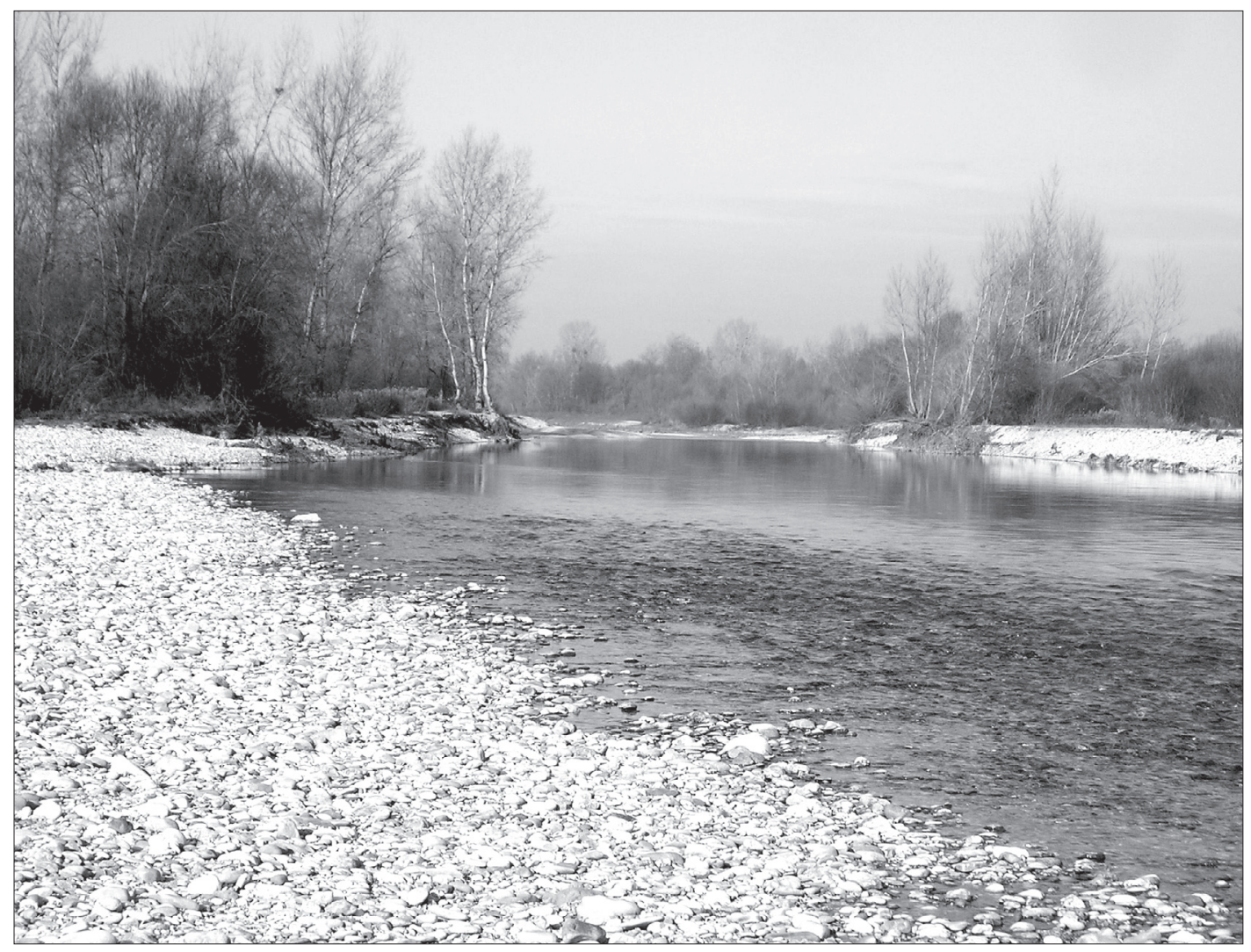

Obr. 3. Řeka Dráva v blízkosti místa nálezu, situace po těžbě štěrkopísku. Foto M. Šimek.

Fig. 3. Drava river near the location of the find, after the rehabilitation of the gravel pits. Photo by $M$. Šimek.

the two central lines. The blade does not have a central ridge, but the edges rise slightly towards the central part, so that the cross-section is lenticular. The sword is partially covered with a patina which has a more pronounced green colour on one side. The lower part of the blade is brown and not covered with a patina. A horizontal crack is visible which is associated with a slight deformation in the lower third of the blade (Fig. 4: B). The damage on the surface probably occurred during the extraction of the sword which is evident in the fresh scratches not covered with a patina. The tip of the blade is also slightly bent like it was exposed to vertical pressure. The whole sword is deformed in such a way that the upper and lower parts of it are bent in opposite directions ( Fig. 4: C; 5: C). The entire edge of the butt is also damaged which is especially noticeable on the remains of the holes of the rivets. All the edges are bent in the same direction, which might have occurred when the handle was detached by force. On the blades, we can see indentations, folded edges, notches, which is reminiscent of the damage caused by striking. Some damage on the surface was caused in recent times during the gravel separation when the sword was found. The scratches are recent, and not covered with a patina. 


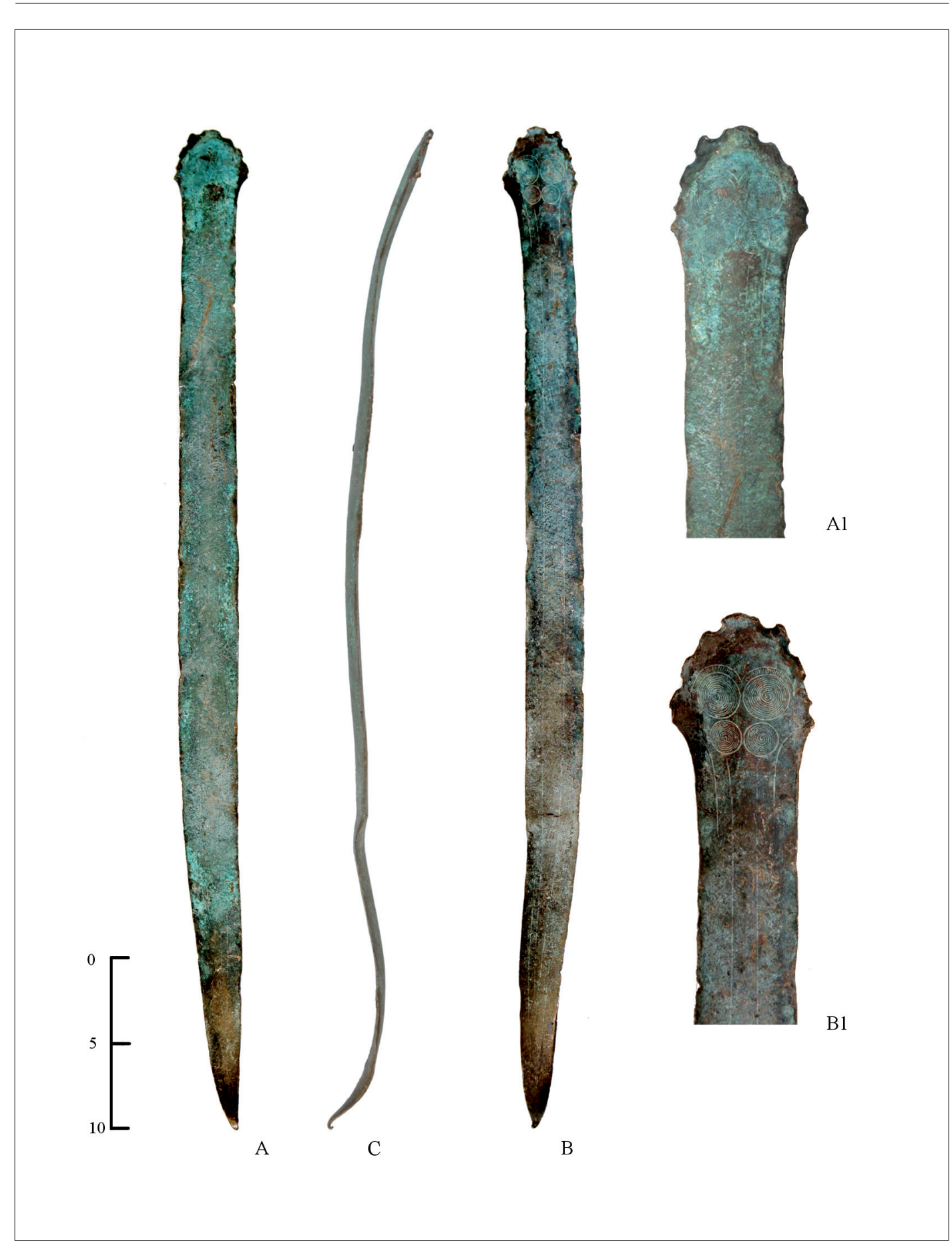

Obr. 4. Meč z řeky Drávy. Foto A. Švoger.

Fig. 4. Drava river sword. Photo by A. Švoger. 


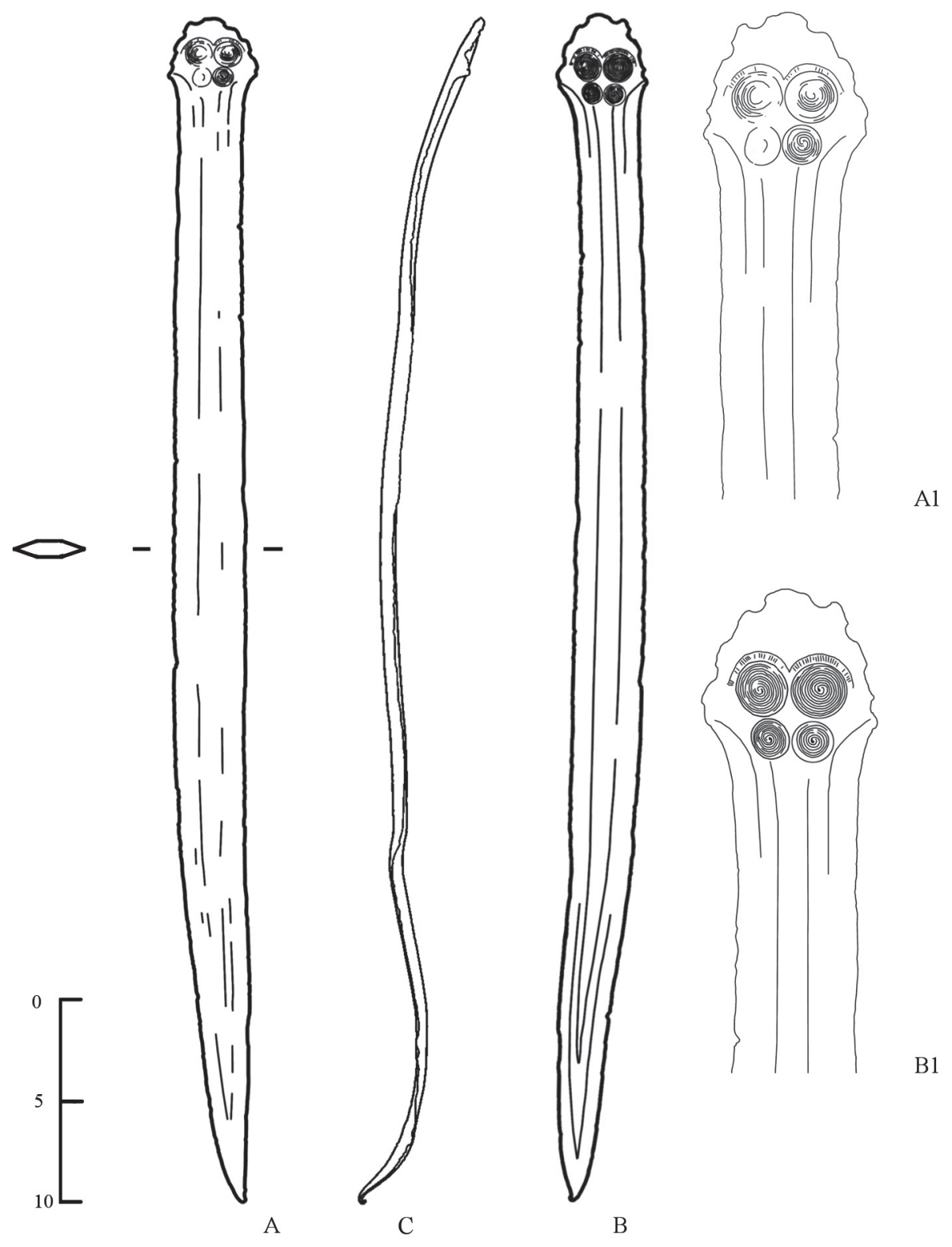

Obr. 5. Mež z řeky Drávy. Kresba M. Matijaško.

Fig. 5. Drava river sword. Drawing by M. Matijaško. 


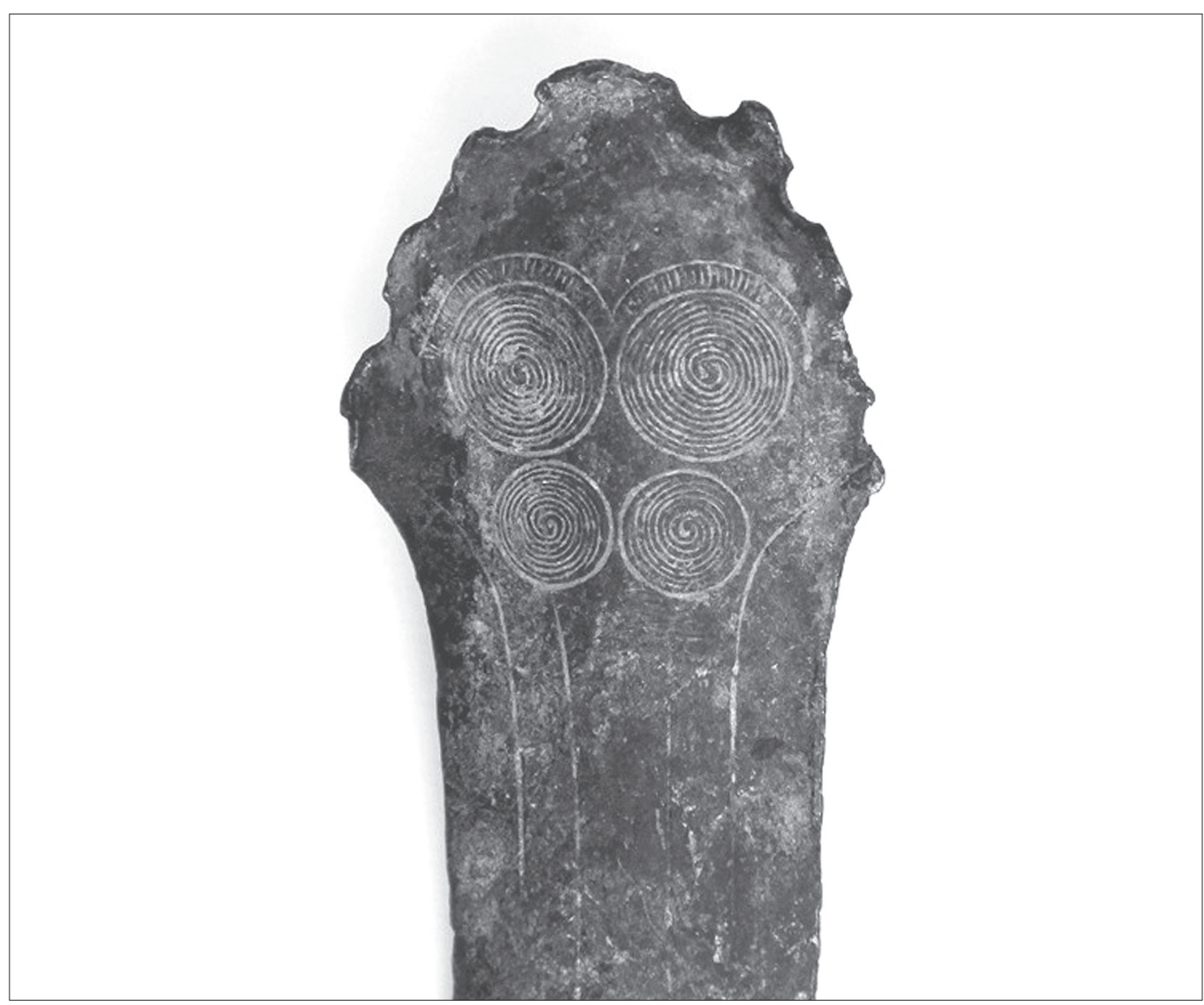

Obr. 6. Detail výzdoby meče. Foto A. Švoger.

Fig. 6. Sword detail with the ornament. Photo by A. Švoger.

\section{Analysis}

Considering the sword is an accidental find, relative dating is possible only on the basis of typological characteristics.

What first attracts attention on the Drava river sword is definitely its well-preserved ornament in the form of a mirrored set of spiral motifs. Ornament such as this one, but also in the form of a semicircle, oval or horseshoe, is characteristic of the swords of the Sauerbrunn-Boiu group ${ }^{3}$. The genesis of the group, characteristics of both types of swords, their similarities and differences, as well as the criteria for the classification are based on different approaches to the issue and vary from author to author (e.g. Foltiny 1963-1964, Cowen 1966, 265-269; Hänsel 1968, 34-39; Pittioni 1985, 53; Kemenczei 1988, 36-39; Neumann 2009). The analysis of numerous decorated swords with wide dispersion and their classification based on the method of fixing the hilt, shape of butts or tangs, number of rivets, length and cross-section of the blade, and type of ornament, have resulted in numerous local types and variants, typically named after the site of the find (Bianco Peroni 1970, 
38-50). The number of names for different types of swords based on the place where they were found leads to inconclusiveness, ambiguity and confusion. Recently, a terminology that comes from the design and decorative specifics of swords was adopted for the classification of the Sauerbrunn-Boiu group (Neumann 2009). The rich ornament on the butt of the Drava river sword (Fig. 6) suggests its association with the already mentioned Sauerbrunn-Boiu group from the Middle Bronze Age, or the Boiu type with a mirrored spiral motif engraved on both sides of an imaginary vertical axis of the butt. However, the typical ornament is not associated with a straight blade unknown among the Sauerbrunn as well as Boiu swords. Blades that are expanded in the upper part, with an engraved ornament that follows the expansion, and a prominent central ridge are what determines the typology of the group (Cowen 1966, 267-269; Schauer 1971, 20, 96). The blade of the Drava river sword with its almost straight form, shallow engraved lines along the edges, without a central ridge and a lenticular cross-section has a completely different shape. Typological disparity between the two elements - ornament on the butt and the form the blade, is characteristic of this sword. The third criterion important for the classification would be the way the hilt was fixed but given the damage to the butt, it can not be applied. Therefore, based on these two elements and their unusual combination, which is uncommon for the development of the group, types and isolated variants, we will try to roughly determine the dating of the sword, the latest among Bronze Age swords from the water milieu in Croatia (Glogović 1996; Glogović 1998). According to Neumann's classification of decorative shapes (Neumann 2009, 99, Abb. 2 ), the ornament on the Drava river sword represents a more developed ornament, and it is most like the $2 \mathrm{~b}$ variant where two circular patterns with concentric circles, or more rarely spirals, are located on either side of the central ridge. Below them are two filled but smaller circles. The ornament on the Drava river sword does not fully fit the $2 \mathrm{~b}$ variant. The difference is a more elongated ornament of several parallel engraved lines that descend from the butt onto the blade (Neumann 2009, 99, Abb. 2, 2b). This ornament is not present on the Drava river sword. It is indicative that certain variants of the ornament correspond with certain variants of the construction of the hilt. Therefore, it was determined that the developed ornament ( $2 \mathrm{a}$ and $2 \mathrm{~b}$ variants) found on the Drava river sword is almost exclusively associated with the "structural" Boiu IIb-c type, and that the compatibility of ornament and the construction of the hilt marks the development of the Sauerbrunn-Boiu group (Neumann 2009, 100). The correlation of both categories is a guideline for the development of these swords.

Both developed ornamental forms, $2 b$ in our case, which almost always correlate with swords with a fully developed tang, or the Boiu IIb-c type, are predominant in the final phase of the Middle Bronze Age, Br C2 (Neumann 2009, 106). When mentioning the ornament on the Drava river sword, it should be noted that it has a relatively rare combination of two double mirrored spirals (Fig. 6). With Boiu swords and their variants, modifications of two spirals combined with a semicircular band or volute motifs are more common. A ornament very similar to the Drava river sword is present on a sword from Cividale del Friuli attributed to the Teór type, the last step in the development of Boiu swords, tentatively dated in the Br B2 - C2 period (Bianco Peroni 1970, 46-50; Urban 1993/2, 389, T. 3:6). The well preserved blade is another important factor for determining the chronology of our sword. The straight blade does not have a central ridge, but a low and tenuous thickening, visible only in the cross-section. The blade has almost parallel 
edges, slightly expanded in the middle. Two engraved lines that go from the butt to the top, following the expansion, are supplemented by shorter lines at the beginning and at the end of the blade. This blade completely deviates from the curved blades with a strong central ridge and a curved ornament recognizable among the specifically decorated and shaped Sauerbrunn-Boiu swords. Attributing the blade to a particular type of sword when the upper part with the hilt was not preserved is very problematic. However, the butt on our sword is partially preserved, but it and the blade form an atypical and undetermined combination, a sort of hybrid. The development of the blade with parallel edges, that began in the 14th century $\mathrm{BC}$, is a sign of a new way of warfare; unlike older, rapier swords used for stabbing, weapons are now used for stabbing and hacking (Schauer 1971, 2; Falkenstein 2007, 39). Changes in combat can be seen in the different designs of the sword blades. The transition from a tapered blade, with a prominent central ridge and high and narrow cutting edges, towards a straight blade, with parallel edges and central thickening, is indicative of a change in the primary use of swords. They were used less for stabbing, and more frequently for striking and cutting (Mödlinger 2011, 163). Judging by its form, the Drava river sword shows tendencies towards new military technology and new times. With further development during the Late Bronze Age, the lower part of the blade was expanded thus becoming suitable for hacking, but this feature is more representative of the Urnfield culture (Schauer 1971, 2; Dular 1974, 17; Harding 1995, 9). A straight blade with engraved lines that follow it, and a simple lenticular cross-section are characteristic of some types of swords from the transition period between the Tumulus and Urnfield cultures, the end of $\mathrm{Br} \mathrm{C}$ and $\mathrm{Br} \mathrm{D}$ periods, so the Drava river sword could be attributed to this time frame. Due to the afore- mentioned atypical construction of the Drava river sword and dual characteristics of its parts, when searching for analogies attention should be focused solely on the characteristics of the blade, regardless of the construction of hilt. It is, as an integral part of swords with a straight blade, completely irrelevant when determining the time frame for the Drava river sword. Similar blades can be found on some swords of the widespread Reutlingen type and its variants, as well as some fragments of lenticular blades with two or more fullers (Schauer 1971, 140, T. 61:414, 419, T. 62:427; Harding 1995, 35-43, T. 12:85, T. 14:95, T. 15:111A; 92, T. 38:314, 315, T. 39:339, T. 41:382). However, Reutlingen swords with new features (wider and shorter blades) still mark a new development (Schauer 1971, 134) that is chronologically younger than the sword from the Drava river. There are also similarities with some Hungarian swords classified in both variants of C-type swords with tang hilts (Kemenczei 1988, 53-58, T. 27:257, T. 30:280A) from the late Tumulus culture / early Urnfield culture. Some swords and fragments of swords, with blades similar to the Drava river sword, were found in several hoards belonging to phase II of the Urnfield culture in northern Croatia. For example, Bošnjaci, Veliko Nabrđe and Poljanci hoards (Vinski-Gasparini 1973, 82, T. 30A:8-10; 85-86, T. 45: 3, 6, 15; 86-87, T. 48:1). They are from the Br D - Ha A1 period noting that in many details of their inventory a strong tradition of the Middle Bronze Age was preserved (Vinski-Gasparini 1973, 125-126).

In an atypical combination, canonical decorative element of the Sauerbrunn-Boiu group, tentatively dated in the final period of the Middle Bronze Age, and the functional element, also tentatively dated to an earlier phase, the late Bronze Age, are united on the Drava river sword. Apparently, it is a distinctively shaped piece, which for reasons unknown to us, unites older ornaments with the novelty in the design 


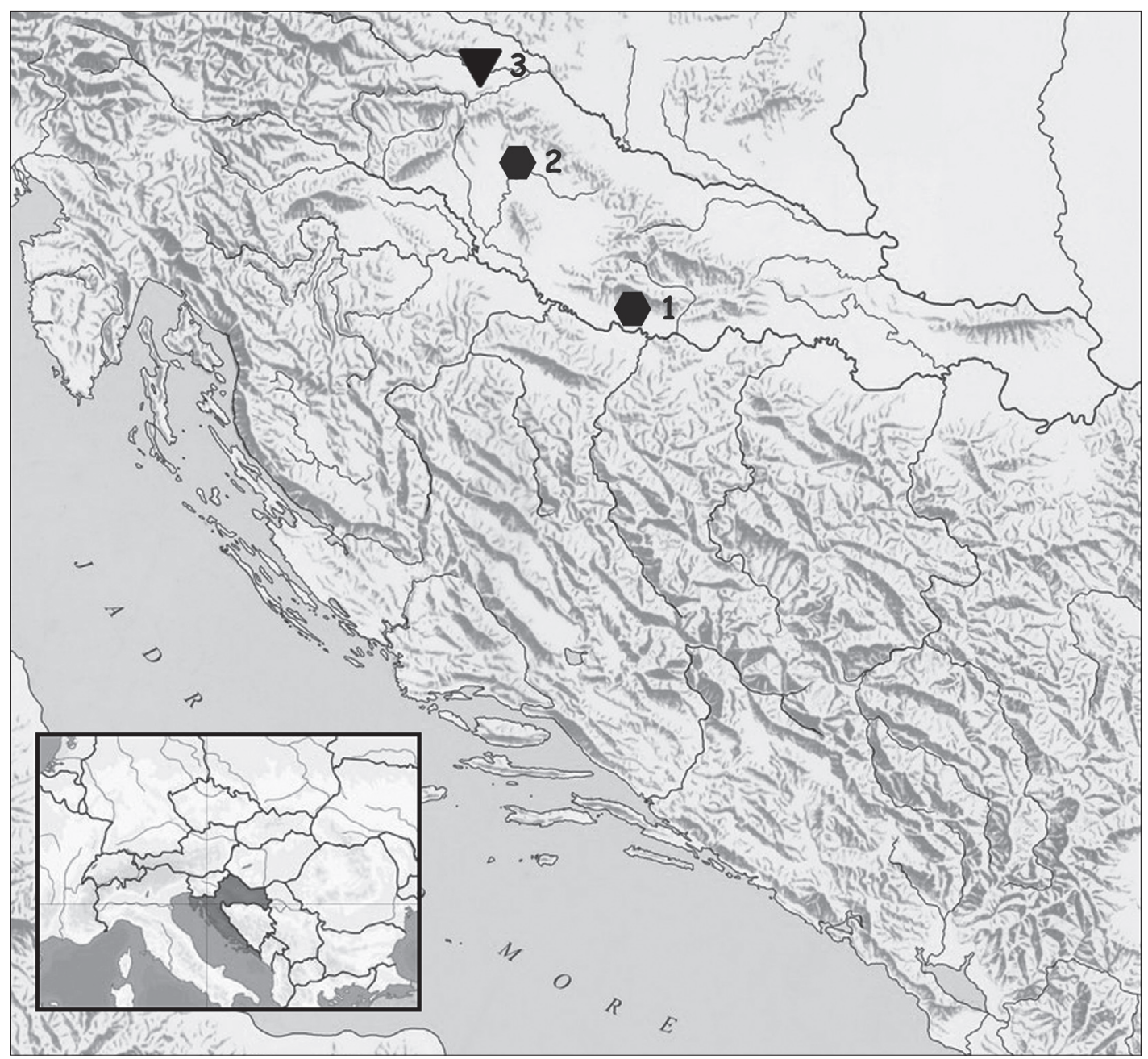

Obr. 7. Mapa Chorvatska. Meče typu Sauerbrunn-Boiu nalezené ve vodních tocích a speciální typ z Drávy: 1: Dolina (řeka Sáva); 2: Bjelovar-Prgomelje (řeka Česma); 3: Varaždin (řeka Drava). Mapu sestavila M. Šimek.

Fig. 7. Map of Croatia. Sauerbrunn-Boiu swords found in water and the special type from the Drava river. 1: Dolina (Sava river); 2: Bjelovar-Prgomelje (Česma river); 3: Varaždin (Drava river). Processing of map by M. Šimek.

of the blade, a combination that could have appeared at the end of the Middle and the beginning of the Late Bronze Age. The sword was probably made shortly after the disappearance of the Sauerbrunn-Boiu group, as it is highly unlikely that the ornament, after having been abandoned, would have stayed in the memory of the master or the client who ordered the sword. The cross-section of the blade is anoth- er detail related to the blade that could help with narrowing the time frame within which the sword was created. The cross-section is very simple, unlike articulated cross-sections from the slightly later $\mathrm{Ha}$ A1 period, so it probably hints at an earlier date or the Br D period. The Drava river sword, which can not be attributed to any defined type, was probably made during the transition period between the end of the 
Middle Bronze Age and the Late Bronze Age, between the $\mathrm{Br} \mathrm{C}$ and $\mathrm{Br} \mathrm{D}$.

Although this find does not belong to the time period of the Sauerbrunn-Boiu group since it was made after it, its impressive ornament, for some reason briefly revived in the Drava river sword, connects it precisely with this group of swords, even as a forgotten predecessor. A list of swords found in water and on locations that were once part of the water milieu, is growing with each day. Some of Europe's major rivers are rich in votive finds, but the number of deposits found in smaller waterways is increasing (e.g. Glogovic 1998; Bartik - Trugly 2006; Pavlin 2006; Gaspari 2007; Turk 2012). Until recently, there was only one Boiu type sword found in a Croatian river; it is a sword from Dolina (Vinski-Gasparini 1973, 179, T. 6:13; Harding 1995, 23, T. 5:26). A few years ago, a Sauerbrunn-Boiu group sword was found by accident in the old Česma riverbed southwest of Bjelovar (Jakovljevic 2012, 25, No. $80)^{4}$. Although the Drava river sword does not have all the characteristics of the group, and it is slightly younger, we have nevertheless connected it with these two "classic" swords (Fig. 7). They are linked because of their specific ornament which is specific to the Sauerbrunn-Boiu group.

\section{A few more questions}

After a long time, this unique sword, placed in water with the intention to remain there, has "emerged" by pure chance from the Drava river and opened a series of questions about the place where it was made and its purpose, whether it was meant for everyday use or rituals, the road it travelled from the place it was made to the special, chosen point where it was placed in water, the meaning of the damage and unusual patina, the time it left our environment, or in other words - the "biography" of the object (Torbrügge 1960; Fontijn 2002). As a spatial, temporal and conceptual category, this sword is part of the extended European ritual deposits of swords in water during the Middle and Late Bronze Age (Hansen 1997). The life of this ceremonial object ended when it was thoughtfully placed in the Drava River, in a place with special natural features (Hansen 1997, 31). The life of the sword began when it was created, but the place of production can not be determined with certainty. A modest number of swords with Sauerbrunn-Boiu characteristics in Croatian rivers indicates they were imported from the territory where there was a greater number of them, from northern Italy or Transdanubia (Neumann, 2009, 100-108, Fig. $6)$, two regions connected through communication and similar symbolic representations in the sphere of spiritual culture during the Middle and the beginning of the Late Bronze Age. Considering the river where the sword was deposited, the fact that it originates in Italy and flows towards the east, perhaps the sword was made in Northern Italy.

The question, was the ritual immersion performed in the vicinity of where it was discovered or somewhere upstream, remains unanswered, although it is more likely it travelled a long way from the location where it was deposited to where it was found, carried by the current. Among others that we always ask when we discover similar objects in water is the question about the socially ingrained rituals and the ceremonial end of the prestigious object (Fontijn 2002, 267, 273-281; Butler - Fontijn 2007, 313; Neumann, 2009, 102-103). The appearance, quality, method of production and decoration imply that the sword from the Drava river was made primarily as a ceremonial, ritual object. Its uniqueness and demanding technological processing with finely engraved decoration on both sides put the secular function in the background. However, this does not mean that the sword could not have also been used as 
a weapon, but it was probably not its primary function (Butler - Fontijn, 2007, 311-313). Even though metallurgical or metallographic tested have not been performed, and it has not been subjected to conservation procedures which would certainly result in important information, older damage is clearly visible on the sword. The whole sword is bent, the edge of the butt was damaged, especially around the holes for the rivets, a horizontal crack on one side of the blade formed where it was bent, the tip of the blade is bent upward, and the whole length on both edges of the blade were damaged. The damage that led to the whole sword being bent, the upper and lower parts are bent in opposite directions, could have occurred through strong pressure on a hard surface (Fig. 4:C; 5:C). This caused the the top of the blade to twist and the blade to break in the lower third portion. The butt was twisted in the opposite direction from the lower part of the blade, but we can also see deformations on its edge that could have been caused when the handle was detached by force (Fig. 6). There is evidence of this in the way the holes for the rivets were damaged, or their partial remains (Mödling, 2007, 114-119). On both edges of the blade we can see the oblong damage in the form of notches where the edge of the blade was damaged by pushing and twisting the metal. Both types of deformation could have been caused by hitting various hard objects with wide or narrow surfaces. Perhaps the sword was deliberately damaged, since there is evidence of it in at least some of the deformations. To bend the entire weapon requires a power greater than the one used during a battle. The characteristic tip of the blade shows it was the support when applying strong pressure on a hard surface. The damage along the entire length on both sides the blade also can not be linked to damage caused in battle because fighting and using the sword for striking would probably have left a mark only in the lower third or maybe half of the blade. Perhaps the butt, from which the handle was removed by force, could have been damaged in combat because the place where the butt and handle are connected is the weakest point on a sword. However, taking into account the general appearance of the sword with all its defects, perhaps it was ritually damaged before it was deposited in the river (Nebelsick 1997; Fontijn - Theunissen - van Os - Amkreutz 2012). Without a more thorough analysis, it is difficult to determine whether some deformations on the sword are the result of a battle, and others the result of intentional and ceremonial damage to the sword. Or, maybe, all deformations conceal violent actions of destroying a wonderful and precious weapon before sacrificing it and marking its end. The oxidation process can give us some information about the context of the deposit. The green patina, which covers the entire surface of the sword, indicates it was placed in a dry environment with oxidation processes. One side is covered with a thicker green layer although in some places, especially at the tip of the blade, we can see the brown surface of bronze. On the other side, the green patina is less pronounced, and the brown colour covers the sword from the tip to the middle of the blade although it is covered by a thin green layer in some places.

Since the brown colour indicates it spent significant time in water that did not allow the oxidation, we expected to see it on the sword from the Drava river (Fontijn 2001, 41-42; Fontijn Theunissen - van Os - Amkreutz 2012, 211-212). However, a combination of oxidized and unoxidized surfaces, more pronounced on one side of the sword, indicates that at one point the position and conditions it was in changed. The original humid environment did not allow the oxidation of the material, but after a while conditions had for some reason changed causing chemical changes on the sword and corrosion 
of the surface. The patina gradually covered the parts of the sword that were exposed to oxygen, while other parts, such as the lower part of the blade, were still protected by a wet layer and remained without a patina with a distinctive brown colour. Where was the sword after it was deposited, when did its position and conditions change? Maybe it was recently uprooted from its original position during the work carried out on the river, and for some time experienced different circumstances that caused changes on its surface? But in order for such a patina to form, it takes a long period of time... There are still many questions about this sword.

1) The mosaic of our distant past becomes clearer and more complete with every detail, assumption or discovery that we add to it. A modest contribution to uncovering one prehistoric period is presented in this paper about a sword bestowed to a river, dedicated to the esteemed Dr. Etela Sudeníková.

2) There is an abundance of data provided by historical cartographic sources about the characteristics of the Drava river in earlier periods. The question of what the observed part of the river looked like in prehistoric periods remains open. However, given the geomorphological factors of lowland areas and a significant slope from west to east, it can be assumed that the Drava river was not a typical lowland river but that in prehistoric times it was a fast and dynamic, rich with forks, meanders and sandbanks (Marković 1983, 26; Obadić 2007, 303).

3) Even though it turned out that the sword that gave the first name of the group was not found in Sauerbrunn but Pöttsching the well established name is still used (Laue 1985, 57, 61).

4) The sword was only preliminarily mentioned in the listed paper, and its publication is being prepared.

Translated by: Nataša Đurđević

\section{References}

Bartik, J. - Trugly, S. 2006: Dva bronzové meče $\mathrm{z}$ riečnych tokov/Zwei Bronzeschwerter aus Flussläufen, Zborník Slovenského národného múzea C, Archeológia 16. Bratislava, 45-54. https://snm. academia.edu/jurajbartik (28. 06. 2016).

Bianco Peroni, V. 1970: Die Schwerter in Italien/ Le spade nell'Italia continentale. Prähistorische Bronzefunde Abt. IV, Band 1. München.

Butler, J. J. - Fontijn, D. R. 2007: Spirraling from the Danube tu the Meuse - the metal-hilted sword from Buggenum (Netherlands, Limburg). In: Burgess, L. - Topping, F. - Lynch, F. (eds): Beyond Stonehenge. Essays on the Bronze Age in Honour of Colin Burgess, Oxford, 302-315. https://www. academia.edu/1230167/Spiralling_from_the_ Danube_to_the_Meuse-_the_metal-hilted_sword_ from_Buggenum_Netherlands_Limburg_(17.03. 2017)

Chvojka, A. - Jirán̆, L. 2013: Bronzezeitliche Funde in Böhmen und ihre Beziehungen zu Fließgewässern.In: Husty, L. - Michálek, J. -
Sandner, R. - Schmotz, K. (eds): Fines Transire 22. Rahden/Westf., 237-244. https://www.academia. edu/7505063/Bronzezeitliche_Hortfunde_ in_B\%C3\%B6hmen_und_ihre_Beziehungen_zu_ Flie\%C3\%9Fgew\%C3\%A4ssern (20. 07. 2016).

Cowen, J. D. 1966: The Origins of the Flanged-hilted Sword of Bronze in Continental Europe, Proceedings of the Prehistoric Society for 1966, Vol.XXXII. London, 262-312.

Dular, J. 1974: Bronasti jezičastoročajni meči iz Slovenije/ Die bronzenen Griffzungenschwerter aus Slowenien. Varia archaeologica, knjiga 1. Brežice, 11-29.

Falkenstein, F. 2007: Gewalt und Krieg in der Bronzezeit Mitteleuropas, Bericht der Bayerischen Bodendenkmalpflege 47/48 (2006/07), München, 33-40.

Fontijn, D. R. 2002: Sacrificial landscapes. Cultural biographies of persons, objects and "natural“ places in the Bronze Age of he southern Netherlands, c.2300-600 BC, Analecta Praehistorica Leidensia 33/34 ( 2001/2001), Leiden. https://www.academia.edu/1242949/Sacrificial_ landscapes._Cultural_biographies_of_persons_ 
objects_and_natural_places_in_the_Bronze_Age_ of_the_southern_Netherlands_c._2300-600_BC (19. 03. 2017).

Fontijn, D. R. - Theunissen, L. - van Os, B. - Amkreutz, L., 2012: Decirated and „killed"? The bronze sword of Werkhoven, Analecta Praehistorica Leidensia 43/44, Leiden, 205-213. https://www. academia.edu/3136505/Decorated_and_killed_ The_bronze_sword_of_Werkhoven (17.03.2017).

Foltiny, S. 1963-1964: Zwei neue Boiu-Schwerter und ihre Zeitstellung, Sborník ČSAV III. Brno, 269-276.

Gaspari, A. 2007: Drugi bronastodobni meč iz Blejskega jezera pri Mlinem (Gorenjska, Slovenija)/ The second Bronze Age sword from Lake Bled near Mlino (Gorenjska, Slovenia). Scripta praehistorica in honorem Biba Teržan. Situla 44. Ljubljana, 231-248.

Glogović, D. 1996: Mačevi s jezičastim rukohvatom iz Dalmacije u svjetlu nalaza iz rijeke Cetine/ Flangehilted swords from Dalmatia in the light of new finda from the Cetina river, Vjesnik arheološkog muzeja u Zagrebu, 3. ser XXVIII-XXIX (19951996). Zagreb, 9-22.

Glogovic, D. 1998: Bronze Age Swords: Aquatic Finds from Croatia and the Neighbouring Regions. In: Hänsel, B. (ed.): Mensch und Umwelt in der Bronzezeit Europas/ Man and Environment in European Bronze Age/. Kiel, 567-570.

Hansen, S. 1997: Sacrifitia ad flumina - Gewässerfunde im bronzezeitlichen Europa. In: Menghin, W. - Hänsel, B. (eds.): Gaben an die Götter. Schätze der Bronzezeit Europas. Bestandskataloge Band 4. Berlin, 29-34.

Hänsel, B. 1968: Beiträge zur Chronologie der mittleren Bronzezeit im Karpatenbecken. Beiträge zur ur- und frühgeschichtlichen Archäologie des Mittelmeer-Kulturraumes Band 7. Bonn.

Jakovljevic, G. 2012: Registar arheoloških nalaza i nalazišta Bjelovarsko-bilogorske županije. Bjelovar.

Kemenczei, T. 1988: Die Schwerter in Ungarn. Prähistorischesche Bronzefunde Abt. IV, Band 6 . München.

Laue, S. 1985: Das namengebende Schwert vom „Typ Sauerbrunn“, Wissenschaftliche Arbeiten aus dem Burgenland, Bd. 71. Eisenstadt, 57-63. https://www.academia.edu/2018751/Das_na-
mengebende_Schwert_vom_Typ_Sauerbrunn_ (11. 07. 2016).

Marković, M. 1983: Geografske i historijske odrednice Varaždina tijekom proteklih 800 godina. In: Mohorovičić, A. (ed.): Varaždinski zbornik. Varaždin, 25-38.

Mödlinger, M. 2007: Herstellung und Qualität mittel- und spätbronzezeitlicher Schwerter aus Österreich, Das Altertum, Band 52, Berlin, 101-130. https://www.academia. edu/1982009/2007._Herstellung_und_Verwendung_mittel-_und_sp\%C3\%A4tbronzezeitlicher_ Schwerter_aus_\%C3\%96sterreich._Das_Altertum_52_101_130 (20.03. 2017)

Mödlinger, M. 2011: Ritual objects or powerful weapon - the usage of Central Europe Bronze Age swords. In: Uckelmann, M. - Mödlinger, M. (eds.): Warfare in Bronze Age Europe: Manufacture and Use of the Weaponry. British Archaeological Reports. International Series 2255. Oxford, 153-166. https://www.academia. edu/835469/M\%C3\%B6dlinger_M._2011._Ritual_object_or_powerful_weapon_the_usage of_Central_Europe_Bronze_Age_swords_in Uckelmann_M._M\%C3\%B6dlinger_M._ed_._ Warfare_in_Bronze_Age_Europe_Manufacture and_Use_of_Weaponry._British_Archaeological_ Reports_International_Series_2255_153_166 (17. 03. 2017)

Nebelsick, L. D. 1997: Auf Biegen und Brechen. Ekstatische Elemente bronzezeitlicher Materialopfer - Ein Deutungsversuch. In: Menghin, W. - Hänsel, B. (eds.): Gaben an die Götter. Schätze der Bronzezeit Europas. Bestandskataloge Band 4. Berlin, 35-41.

Neumann, D. 2009: Bemerkungen zu den Schwertern der Typenfamilie Sauerbrunn-Boiu-Keszthely. In: Bagley, J. M. - Eggl Ch. - Neumann, D. - Schefzik, M. (eds.): Alpen, Kult und Eisenzeit. Festschrift für Amei Lang zum 65. Geburtstag. Internationale Achäologie: Studia honoraria Bd. 30. Rahden/Westf., 97-114. https://www.academia. edu/3324410/Bemerkungen_zu_den_Schwertern_der_Typenfamilie_Sauerbrunn-Boiu-Keszthely. (20. 07. 2016).

Obadić, I. 2007: Međuodnos ljudi i rijeke Drave na području varaždinske Podravine u novom vijeku, 
Radovi Zavoda za znanstveni rad HAZU Varaždin br. 18. Varaždin, 301-325.

Pavlin, P. 2006: Srednjebronastodobni levoročni jezičastoročajni srpi in meč iz Ljubljanice/ Middle Bronze Age left-handed tanged sickles an a sword from the Ljubljanica River, Arheološki vestnik 57, Ljubljana, 69-83.

Pittioni, R. 1985: Ein neues Schwert vom Typus Boiu, Wissenschaftliche Arbeiten aus dem Burgenland, Bd. 71. Eisenstadt, 51-63.

Potočnik, M. 1989: Bakreno- in bronastodbne najdbe iz Bistre in Ljubljanice na Ljubljanskem barju, Arheološki vestnik 39-40 (1988-1989), Ljubljana, 387-400.

Schauer, P. 1971: Die schwerter in Süddeutschland, Ósterreich und der Schweiz I. Prähistorische Bronzefunde Abt. IV, Band 2. München.

Torbrügge, W. 1960: Die bayerischen Inn-Funde, Bayerische Vorgeschichtsblätter, Heft 25, München, 16-69.
Turk, P. 2012: Gewässerfunde aus der Ljubljanica, Slowenien. In: Sölder,W., Höck, A. (eds): Waffen für die Götter. Krieger Trophäen Heiligtümer. Innsbruck, 131-133. https://www.academia. edu/7847630/Gew\%C3\%A4sserfunde_aus_der_ Ljubljanica_Slowenien (10.06. 2016).

Turk, P. - Gaspari, A. 2009: Gifts to the gods and ancestors. In: Turk, P. - Istenič, J. - Knific, T. Nabergoj, T. (eds): The Ljubljanica - a River and its Past. Ljubljana, 66-71. https://www.academia. edu/3045713/P._Turk_A._Gaspari_Gifts_to_the_ Gods_and_Ancestors (20.07. 2016).

Urban, Th. 1993: Studien zur mittleren Bronzezeit in Norditalien /Teil 1, Teil 2. Universitätsforschungen zur prähistorischen Archäologie, Band 14. Bonn.

Vinski-Gasparini, K. 1973: Kultura polja sa žarama u sjevernoj Hrvatskoj. Monografije 1. Zadar. 


\section{The Drava River Sword}

In 2006, an interesting and typologically unique bronze sword was accidentally found during the extraction and separation of gravel in the old riverbed of the Drava river in northwest Croatia. The site is located near Varaždin in the area where the river has preserved its natural characteristics of meanders, backwaters, sandbanks and islets for quite a long time. Even though Drava is a lowland river, in the past, it was strong and fast and changed its flow often flooding the surrounding area. The sword is $57 \mathrm{~cm}$ long; the butt for fixing the hilt is $4.5 \mathrm{~cm}$ wide and $3.5 \mathrm{~cm}$ long. The blade is 3 to $3.4 \mathrm{~cm}$ wide, and $0.8 \mathrm{~cm}$ thick. The weight of the sword is 594 grams. It is covered with a mostly natural patina, and the lower part of the blade is damaged. It is stored in the Varaždin City Museum, inv. no. GMV60156. Analysing different parts of the sword, which at first glance seems to belong to the SauerbrunnBoiu group from the Middle Bronze Age because of the standard ornament, has led to the data regarding the time of its creation and use. The patina on the sword and the oxidation can provide useful data about where it was kept, and the conditions in which the object was after it was placed in water. While the green patina and the oxidation process on the surface of the object tell us it was placed in a dry environment, the brown or gold colour of bronze show it was also somewhere humid and wet. Based on the unusual combination of green patina and brown surface on the sword, we can conclude that the sword first spent significant time in wet conditions where there was no oxidation. After a while, for unknown reasons, the object was moved to a dry environment. Probably, only the lower part of the blade still remained in contact with water and preserved the brown colour, while the upper part of the sword was slowly covered in green patina. No information can be given about why the sword was moved, the time that passed between where it was originally deposited and the new conditions, the reasons for these major changes and the time that elapsed between the time it was exposed to oxidation and the moment it was discovered. Many questions about this sword still remain open.

The summary is shortened so there are some very important information on the sword in question missing (such as type, combination of types, characteristics, date etc.) - all the information esential to the main text. 
Šimek

The Drava River Sword

\section{Marina Šimek}

- Rudolfa Horvata 36, 42000 Varaždin, Croatia

marina.simek@optinet.hr 